\title{
The Effects of Demand and Interest Rates on Investments, Evidence of Overinvestment from Two Behavioral Experiments
}

\author{
Christian A. Conrad ${ }^{1}$ \\ ${ }^{1}$ University of Applied Science HTW at Saarbrücken, Germany. \\ Correspondence: Christian A. Conrad, University of Applied Science, htw saar, Waldhausweg 14, 66123 Saarbrücken, \\ Germany.
}

Received: December 8, 2021

Accepted: January 10, 2022

Available online: Janaury 17, 2022

doi:10.11114/aef.v9i1.5452

URL: https://doi.org/10.11114/aef.v9i1.5452

\begin{abstract}
This article analyzes the causes of overinvestment and thus investment cycles with two behavioral experiments. In the experimental simulations increases in demand and cuts in interest rates increased unit profits, which led to uncoordinated and thus collectively too high investments (collective error). This made it possible to demonstrate collective errors that led to overinvestment and investment cycles (boom and bust cycles). Central banks and companies should take this into account when making their decisions. The experiments show the fundamental problem of uncoordinated supply adjustment and a tendency on the part of market participants to neglect the behavior of other actors and to underestimate the influence of the market on their own investment decisions.
\end{abstract}

Keywords: overinvestments, cobweb theorem, low interest rate policy, monetary business cycles, boom and bust cycles, collective error hypothesis, efficient market hypothesis, Wicksell hypothesis, behavioral modeling

JEL classification: E 43, E 47, E 58

\section{Introduction}

Companies invest if they can make more profit with more production. Increased prices or cost cuts might be reasons for an augmented profit margin and thus trigger investments. This article analyzes the causes of overinvestment and thus investment cycles with two behavioral experiments (experimental simulation, behavioral modeling). Increases in demand and cuts in interest rates are examined as possible causes for overinvestment, which lead to corresponding increases in profits and thus trigger investments. If economic actors make mistakes in managing capacity, overinvestment can result. The problem is that the market participants do not know by how much their competitors are increasing their capacities and the price only reacts once the capacities are on the market. What if the market players systematically make mistakes because they are not behaving rationally or because they do not have all the information, such as the capacity increases of their competitors? Applying behavioral economics, this essay analyzes the economic behavioral dispositions using models to identify the mistakes actors make in groups (collective error hypothesis). The goal of the paper is therefore to test if increases in demand can lead to overinvestment due to errors made by market participants and if interest rate cuts can lead to overinvestment due to errors made by market participants

In section 2 the existing literature and studies are presented and compared to the experiment presented here. Section 3 explains the experimental design of the study. Finally, the results are presented and conclusions are drawn (section 4 and 5).

\section{Related Literature}

It usually takes a while before capacities can be increased when companies invest. The production facilities must be financed, purchased, delivered and integrated into production. Price increases that lead to overinvestment due to delays in expanding supply are primarily seen in the market for raw materials (Humphreys, 2012). Mining projects take five to ten years to complete. Conversely, mine production is difficult to throttle so that the capacities can continue to be used for production as long as the prices are above the variable costs (Glöser-Chowhound, Hartwig, Wheat \& Faulstich, 2017).

This is in contradiction to the Efficient Market Hypothesis. This hypothesis assumes that all accessible price-relevant information of the past, present and future are known. The efficient market hypothesis in financial market theory was 
undisputed until the mid-1980s. Since rational behavior is assumed in principle, irrational behavior or wrong decisions do not influence the price (Sloan \& Stern, 1988; Shleifer, 2000; Menkhoff \& Röckemann, 1994; Fama, 1970). However, the spot prices, but also the future prices, can not take into account the investment decisions of the market participants.

Conversely, there is a direction in economics that repeatedly emphasized the difficulties in adapting supply and demand. As early as 1966, Leontief (1966) pointed out that time lags between supply or demand reactions can massively impair the achievement of market equilibrium. This connection found its way into economics as the cobweb theorem (Waugh, 1964; Ezekiel, 1938).

High raw material prices lead to high investments and capacity expansions and low prices lead to low ones, which increases the probability of over- and undersupply. Market expectations play a decisive role in investment decisions (Humphreys, 2012), which is why future prices also have an influence here. These behavior errors in capacity planning were demonstrated in 1992 by Kampmann's market behavior experiments (Kampmann, 1992; Kampmann \& Sterman, 1996).

Using experiments with students who played the company, Kampmann and Sterman (1996) obtained an overshoot of production at fixed given prices with a subsequent downward adjustment of production as a recession, i.e. boom and bust cycles. They stated that firms have great difficulties catching up with demand due to production delays and the continuous accumulation of inventory imbalances. Kampmann (1992) found out that the increase of prices apparently induces the firms to further increase output. And Glöser-Chowhound, Hartwig, Wheat \& Faulstich 2017 point out that market participants also need information about the other participants. A balance between supply and demand cannot be achieved even in simple markets (Zame, 2008). Shachat and Zhang (2012) conducted experiments with students with reference to the Cobbweb Theorem and found out "that sellers do a miserable job of making optimal investment decisions...."

Knut Wicksell lays the blame for boom and bust cycles at the doorstep of the monetary policy decision-makers and their inappropriate decisions regarding interest controls. In the boom the interest rates are too long to low, creating overinvestments as collective error. The reaction of the central bank is too late and too harsh, creating not just the boom but also inadvertently the bust (Wicksell hypothesis) (Wicksell, 1922; Wicksell, 1968; Grosskettler, 1989).

All these studies show that there appear to be undesirable developments in the markets because not all information is available or correctly applied. The concept of bounded rationality was developed in response to this information problem, implying limited information processing capacities as opposed to complete rationality. A decision that maximizes utility is rationally limited if it takes account of information access and processing (Simon, 1959).

This essay analyzes the economic behavioral dispositions using models to identify the mistakes actors make in groups. Behavioral modeling (Conrad 2015, 2019, 2021) intends to outline the economic framework for behavior in many situations, but do not claim to depict reality. The models should only contain the factors relevant to the decision. They then examine the interaction of many actors sociologically. Behavioral hypotheses are set up, which are then tested on subjects within the framework of the models. The structure of the experiment is explained so that other scientists can reproduce it. According to Popper (1958), the hypotheses apply until they are falsified by experiments with the opposite result. The behavioral dispositions thus determined can in turn be used for new theories and economic policy strategies.

\section{Experimental Design}

We want to answer two questions:

A. Can increases in demand due to systematic errors by companies lead to overinvestment or can companies interpret the price signals and collectively manage the expansion of capacity correctly?

B. Could interest rate cuts trigger overinvestment because companies misinterpret higher profit margins and expand capacity?

The purpose of this paper is therefore to test the two hypotheses:

A. Increases in demand can lead to overinvestment due to errors made by market participants

B. Interest rate cuts can lead to overinvestment due to errors made by market participants

Two behavioral experiments on MS Teams were carried out online with the help of Excel. Increases in demand (game A) and interest rate cuts (game B) were examined as possible causes of corresponding increases in unit profit and thus a trigger for investments.

The two experiments, A and B, were conducted in the summer 2021 and winter semester 2021/22. There were 95 participants in seven groups in game A and 87 students (six groups) in game B, who were participants of different Business Bachelor courses (macroeconomics and political economy) at the University of Applied Science HTW at 
Saarbrücken, Germany. The task of the students was to invest capital like a manager of a company. The participants were asked to maximize the profit, which is the obligation of a manager as agent for a principal (company owner resp. shareholder). Maximal profit in the group resulted in $10 €$ real money as variable compensation. The rules were explained to the students before starting the experiment.

\section{Experiments}

\section{Game A: The Effects of Increases of Demand on Investments}

The goal is to test the following hypothesis: Increases in demand can lead to overinvestment due to errors made by market participants.

The model used was that of a simplified company. Each company (represented by a player) had in the beginning a production capacity (PC) of 500,000 units. The games started with sales (S) of 10 million euros, at a price (P) of 20 euros and cost of 15 euros (C). Thus, the test subjects sold 500,000 goods with their individual company, making a profit (PR) of 2.5 million euros ( $P R=S-C P C$ ) with an equity (EQ) of 10 million. Each company had to decide on its investment (I). There were delays in expanding the range. For example, investments of 2.5 million euros (two rounds of the game) brought 50,000 increased production capacity in 2 years, or 1 million euros more sales at a price of 20 euros ( $40 \%$ or 50 euros per unit of production capacity, $\mathrm{PC}_{t+2}=\mathrm{PC}_{t}+\mathrm{I}_{\mathrm{t}} / 50$ ). Investments decreased equity, while profits increased it. Demand and capacities were included in the price. The ratio between demand and capacity was multiplied by the price of the previous period $\left(\mathrm{P}_{t}=\mathrm{D} / \mathrm{PC} \mathrm{P}_{\mathrm{t}-1}\right)$. Due to the delayed supply increases, the prices only react to the investments after two rounds. Once production facilities were installed they could no longer be dismantled, so the increase in capacity was irreversible. Whoever had the most equity after 10 rounds won and received 10 euros. The demand was changed and entered by the game master. The game began with a demand equal to supply.

\section{Results}

Figure 1 shows the increases in demand in rounds 2, 6 and 10. As a result, the prices in Figure 2 increased and with it the average unit profits $(\mathrm{UP}=\mathrm{PR} / \mathrm{PC})$ in Figure 3. Figure 4 shows the investments of the players. The investments were initiated by the increase in demand or the price and unit profit increases, which were always too high, as can be seen in the subsequent sharp drop in prices and thus also average unit profits (Figure 3). All groups showed similar behavior.

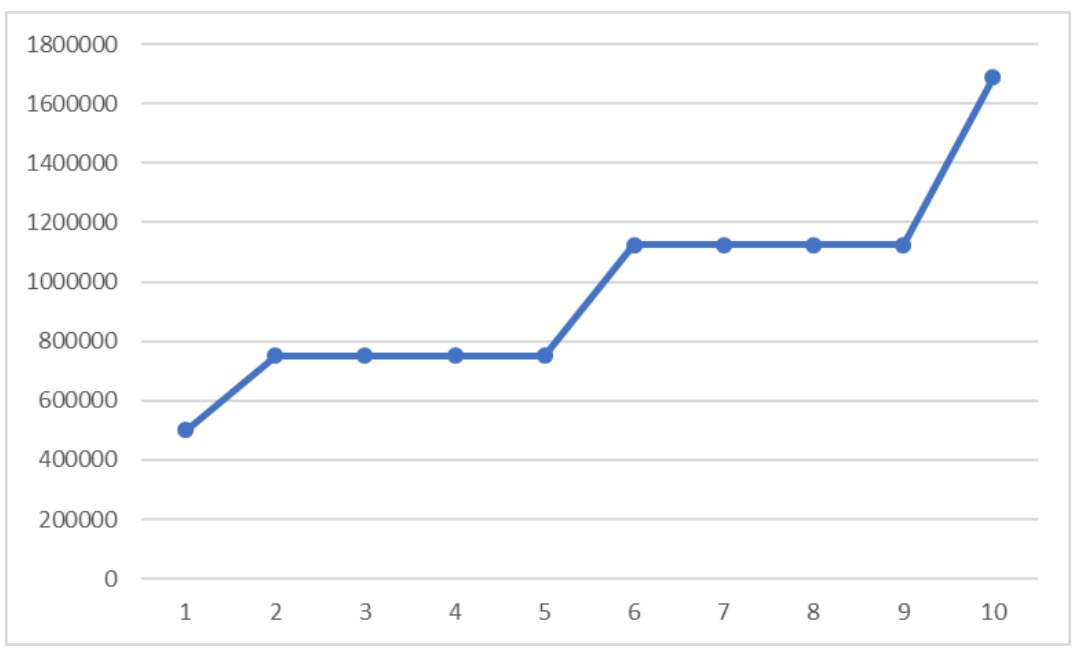

Figure 1. Demand per player in units 


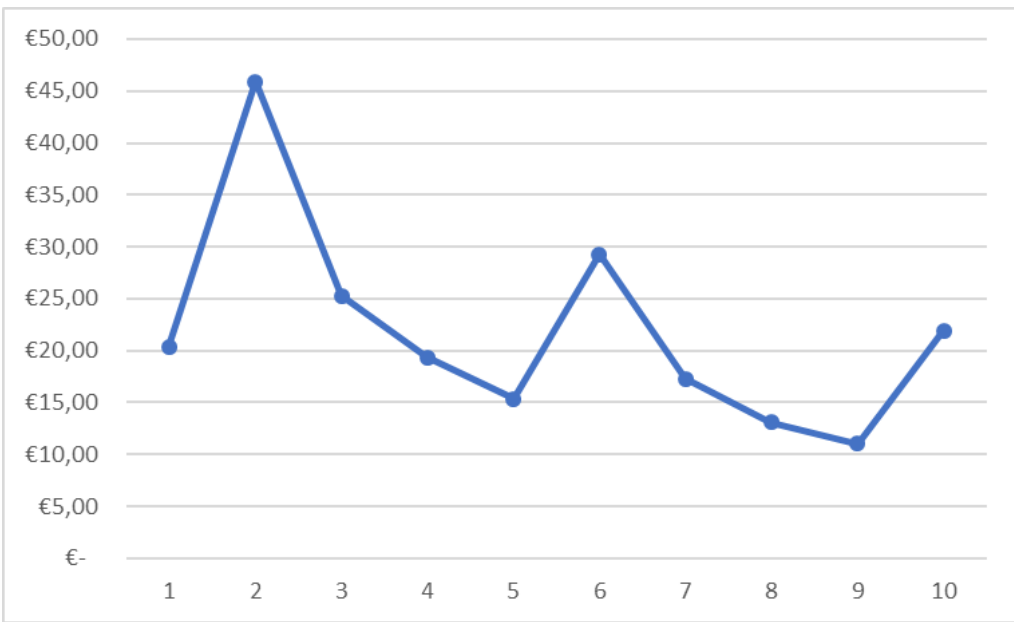

Figure 2. Prices

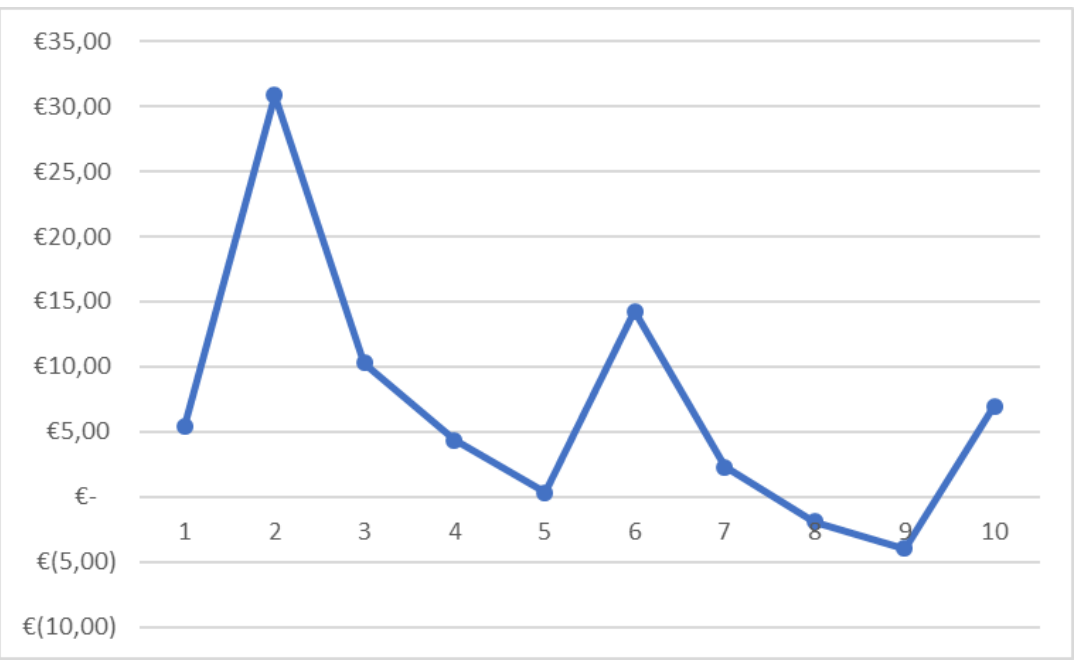

Figure 3. Unit profits

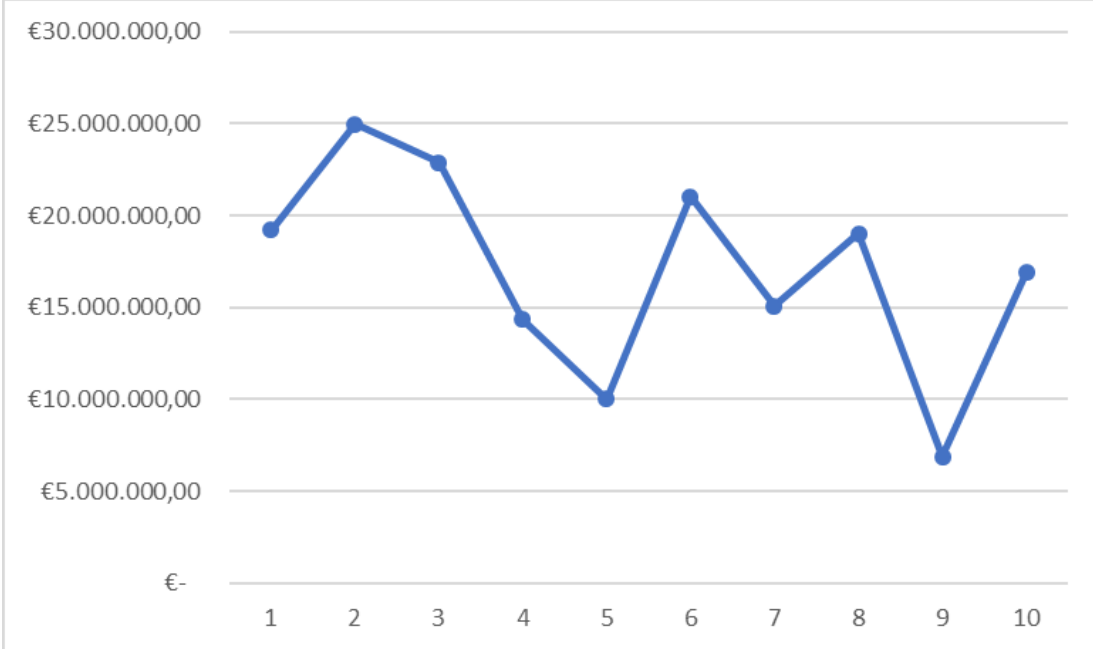

Figure 4. Sum of investments 


\section{Conclusions for game A.}

The first game shows the fundamental problem of non-coordinated supply adjustment among the companies. Game A's hypothesis was supported by the behavioral test. The increase in demand led to price increases, which signaled increases in profits. The companies (test subjects) increased their capacities, but did not know how much their competitors were increasing their capacities. This led to collective errors. The capacities were increased too much, resulting in investment cycles. First there was an upswing when capacity was being built up and then a downturn when prices fell as a result of overcapacity and companies hardly invested any more.

Assuming a profitable equilibrium, an increase in demand creates an oversupply. And even without an increase in demand, there was a tendency towards overinvestment due to the profitable starting position. The increase compared to the original state, however, clearly shows the influence of the increase in demand. Due to a lack of experience, players tended to over-invest. After the game, the test subjects said that they had underestimated the influence of other market participants on the success of their own investment decisions. In practice, the experience with capacity adjustments should not be much higher than in the Excel games, since managers change in the company and the adjustment processes take years (Thaler, 1987).

\section{Game B: The Effects of Interest Rates on Investments}

The aim is to test the following hypothesis: Interest rate cuts can lead to overinvestment due to errors made by market participants.

The model used was that of a simplified company. As before, every company had to make decisions about its investment. Each company (represented by a player) had in the beginning a production capacity (PC) of 500,000 units. New was that the investments were financed by debts. Starting debt capital was 20 million euros. At an interest rate of $5 \%$, the companies paid 1 million euros in interest. The games started with sales (S) of 10 million euros, at a price (P) of 20 euros and cost of 15 euros (C). At a price of $€ 20$, sales were $€ 10$ million. The companies sold 500,000 goods in the first round, making a profit of 1.5 million euros (PR) after deducting the production costs of 15 euros $(\mathrm{C})$ and the 1 million euros in borrowing costs (BC) $(\mathrm{PR}=\mathrm{S}-\mathrm{C} \mathrm{PC}-\mathrm{BC})$. Each company had to decide on its investment (I). There were delays in expanding the range. For example, investments of 2.5 million euros (two rounds of the game) brought 50,000 increased production capacity in 2 years, or 1 million euros more sales at a price of 20 euros $(40 \%$ or 50 euros per unit of production capacity, $\mathrm{PC}_{\mathrm{t}+2}=\mathrm{PC}_{\mathrm{t}}+\mathrm{I}_{\mathrm{t}} / 50$ ). The investments directly increased the borrowed capital and the interest to be paid (in addition to the 15 euros production costs per unit), the remaining profit increases the equity. Demand and capacities were included in the price. The ratio between demand and capacity was multiplied by the price of the previous period $\left(\mathrm{P}_{\mathrm{t}}=\mathrm{D} / \mathrm{PC} \mathrm{P}_{\mathrm{t}-1}\right)$. Due to the delayed supply increases, the prices only react to the investments after two rounds. Once production facilities were installed they could no longer be dismantled, so the increase in capacity was irreversible. Whoever had the most equity after 10 rounds won and received 10 euros. The demand and interest rates were changed by the game master. The game began with a demand equal to supply. The demand was again entered by the game master up to round 6 as equal to supply.

\section{Results}

The first round started with 5\% interest. The demand had not changed. In the second round the central bank cut interest rates to $2 \%$ and in the third round to $0 \%$. The demand was only increased in round 6 (figure 5). The interest rates were reduced from round 2 (see figure 6). This led to a sharp increase in investments (figure 7). The increase in capacity (figure 8), which was delayed by two rounds, then pulled the price (figure 9) down, and thus also the average unit profit $(\mathrm{UP}=\mathrm{PR} / \mathrm{PC}$ ) figure 10). All groups showed similar behavior. 


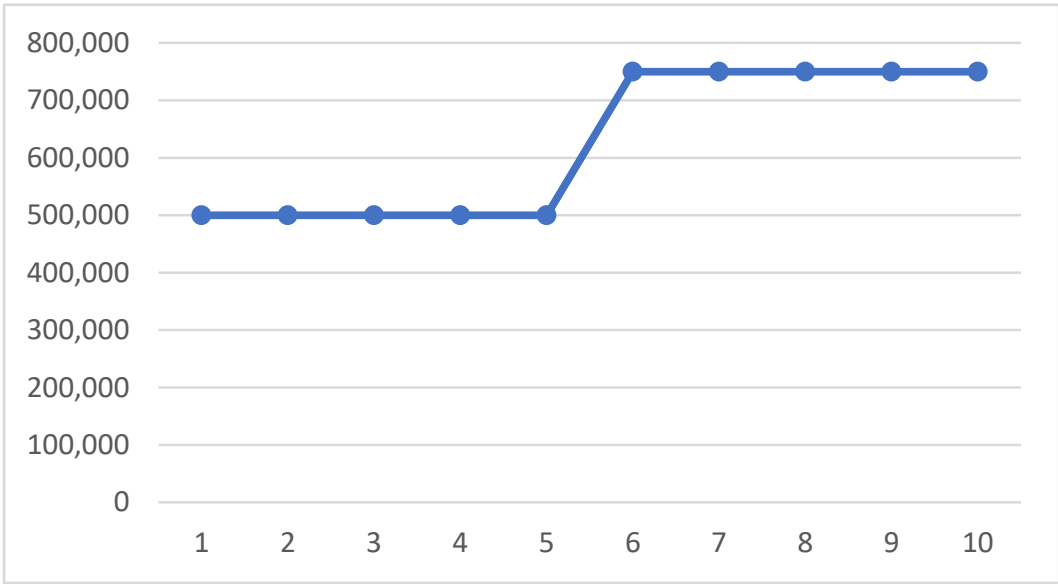

Figure 5. Demand per player

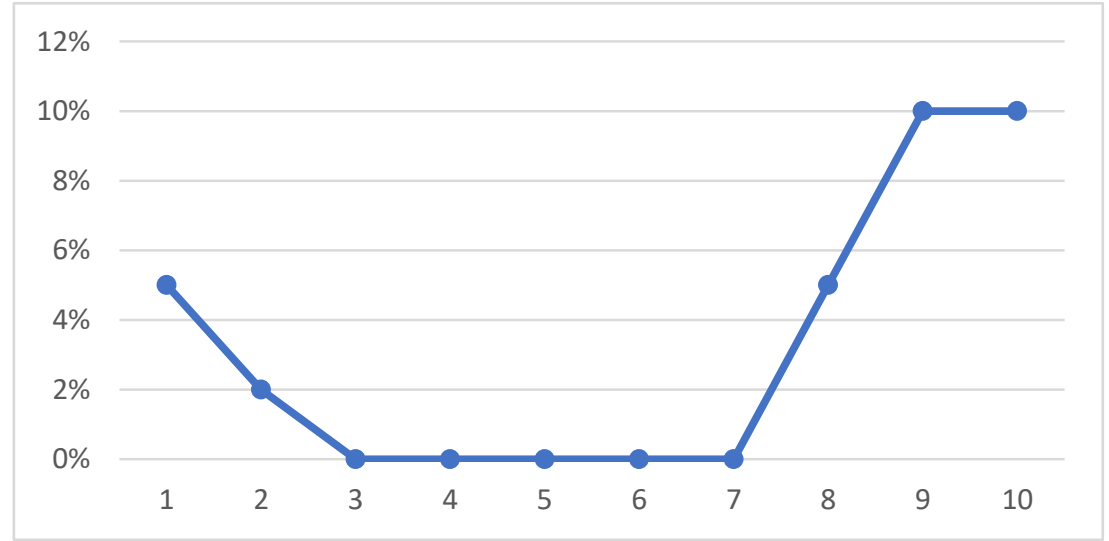

Figure 6. Interest rates

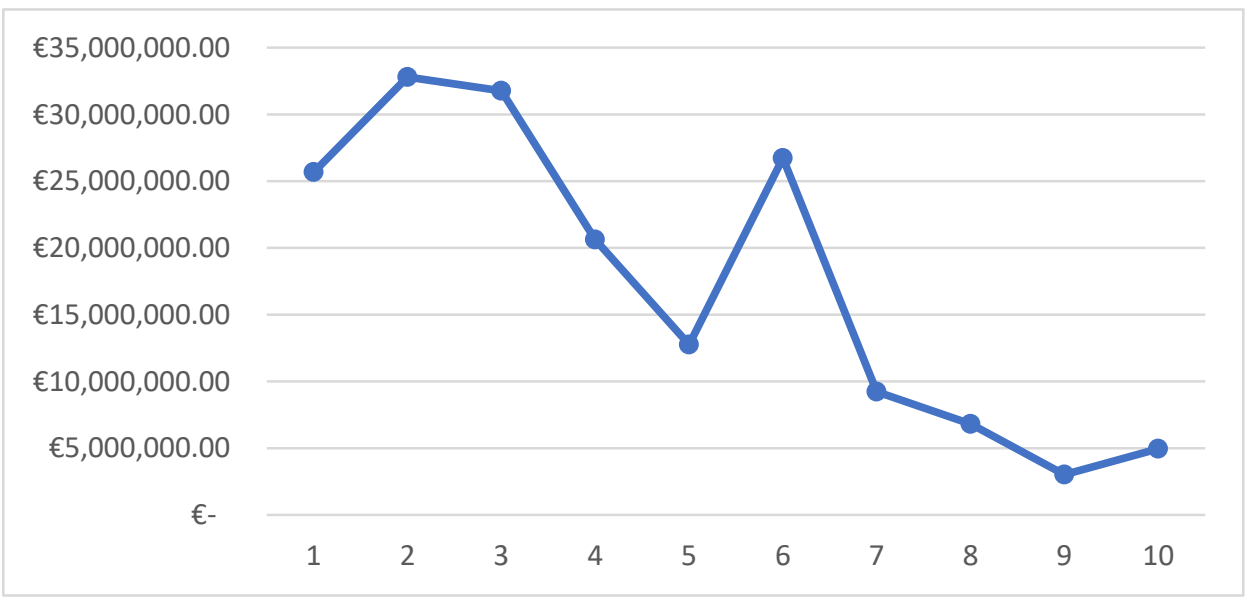

Figure 7. Investments 


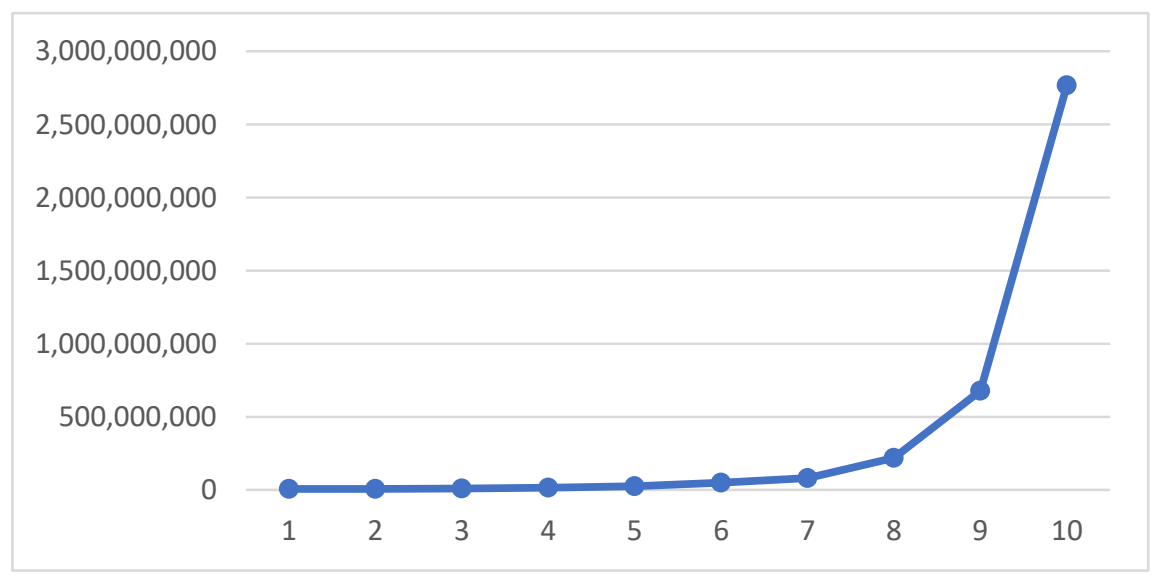

Figure 8. Production capacities

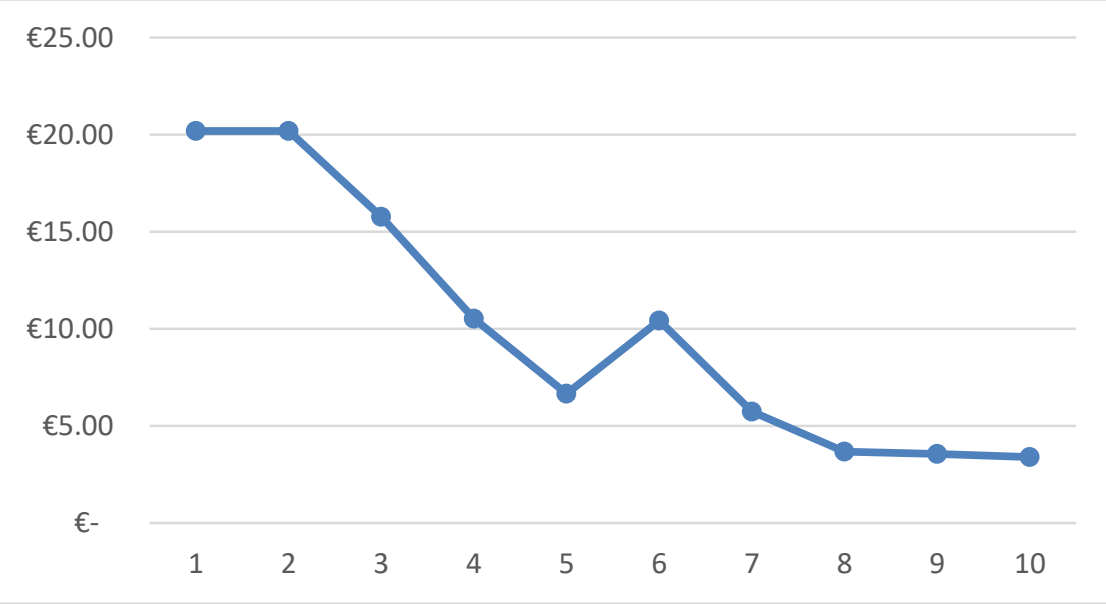

Figure 9. Prices

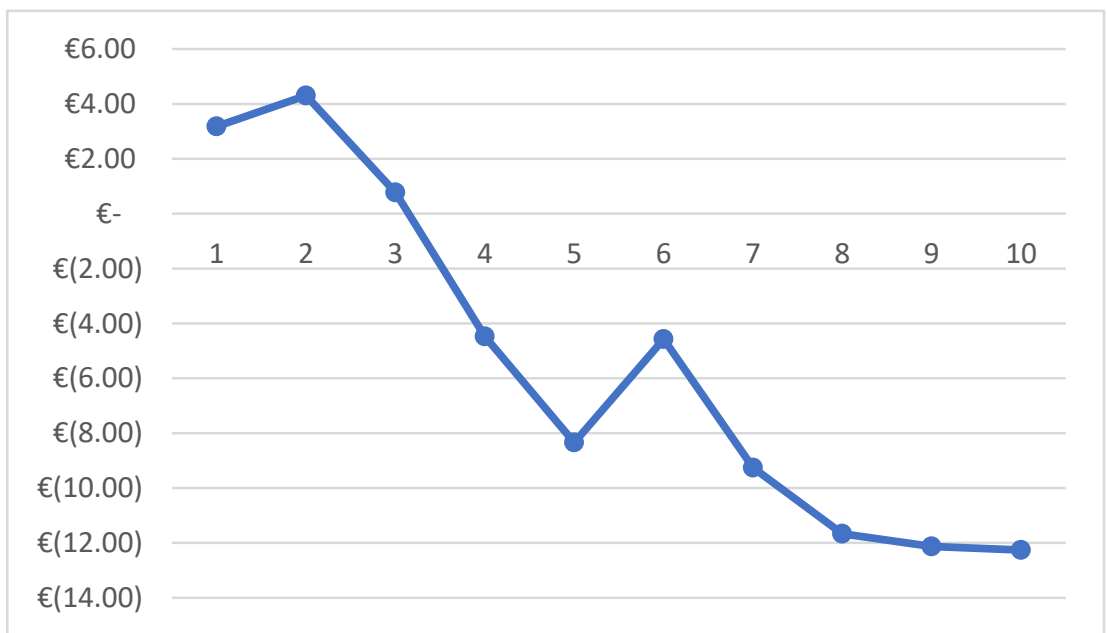

Figure 10. Unit profits

The central bank's reaction to possible inflation was also tested. In the sixth round demand increased by 50\% (figure 5). The prices also rose (figure 5). There was another increase in investments (figure 7). The central bank reacted too late to the increased prices (Wicksell assumption) and first raised interest rates to $5 \%$ in the eighth round and then to $10 \%$ in 
the ninth and tenth round in order to stop inflation (Figure 9). The higher borrowing costs lead to bankruptcies, as equity dropped massively (Figure 11). It is also interesting that the test subjects barely learned from their mistakes with a tendency to overinvest throughout the game. In practice, there would be a reduction in supply through exit from the market, i.e. bankruptcies.

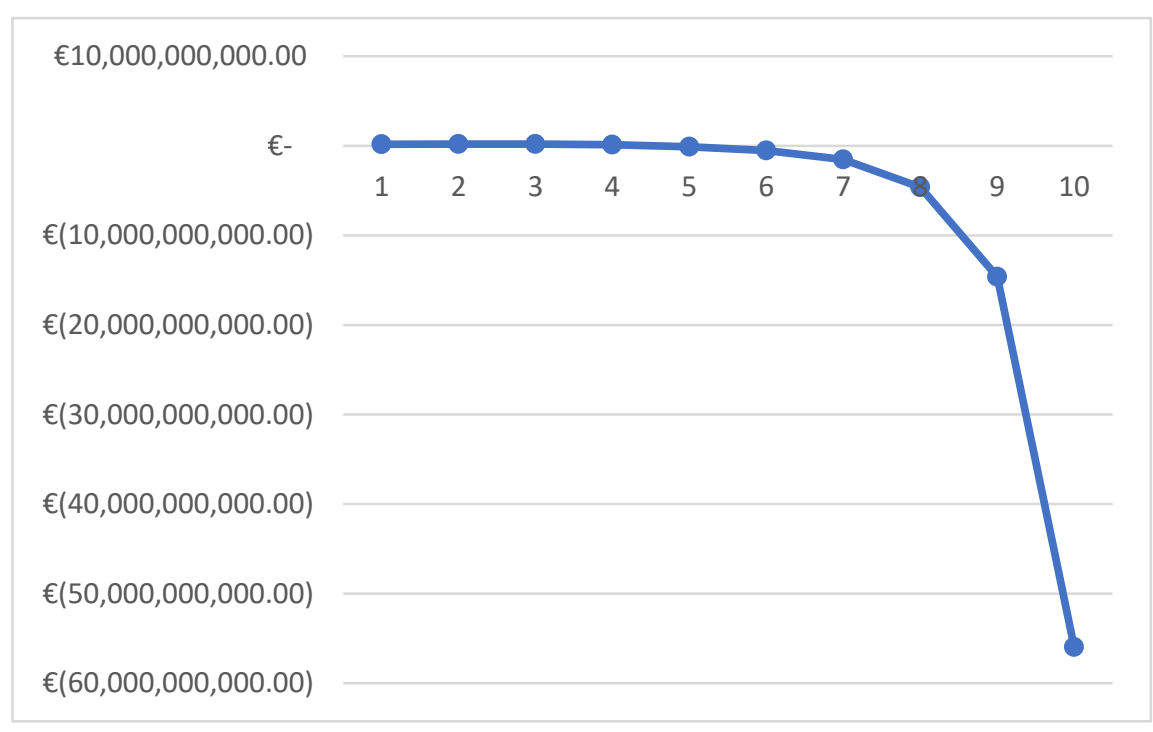

Figure 11. Equity of the companies at the end of each round

\section{Conclusion game $B$}

The experiments confirmed the hypothesis. The interest rate cuts led to unit profit increases. The companies increased their capacities even though prices had not increased. The rate cut thus led to collective errors.

The increase in demand and the associated increase in unit profit also led to overinvestment. The central bank reacted too late and finally raised interest rates too sharply, resulting in massive bankruptcies because the companies were too indebted during the low interest rate phase. Here, too, there was a collective error. The actors assumed that interest rates would remain low. This phenomenon was seen in the financial crisis. The real estate buyers were unable to pay the interest rates that had risen as a result of the Fed's decision, which ultimately triggered the first loan defaults and thus the crisis (Conrad, 2020).

In game B the participants said that the lack of any borrowing costs had triggered a strong psychological impulse in them to access, i.e. to invest. Apparently similar processes take place as those in discounts or closing out sales.

\section{Final conclusion}

In our behavioral experiments increases in demand and cuts in interest rates increased unit profits, which led to uncoordinated and thus collectively too high investments. The result was also a misallocation of resources (capital). This made it possible to demonstrate collective errors that led to overinvestment and investment cycles (boom and bust cycles) and which can be relevant to the economy. Central banks and companies should take this into account when making their decisions. The results of our experiments show that interest rate cuts not only stimulate investment to protect the economy from a recession, but can also encourage overinvestment. A low interest rate policy should therefore not last too long and, above all, the central bank must make clear the time limit for subsidizing borrowing costs. Otherwise the central bank risks bankruptcies and a new recession (boom and bust cycles). In addition, central banks should monitor investment behavior in order to identify overinvestment in good time. In the event of overinvestment, the central bank has to raise interest rates at short notice in order to prevent the economy from overheating and thus the subsequent sharp slump. The central bank must not hold inefficient companies in the market with artificially low borrowing costs (low interest rate policy). The overcapacities have to be eliminated from the market so that the supply can adapt to the demand.

The experiments show the fundamental problem of uncoordinated supply adjustment and a tendency on the part of market participants to neglect the behavior of other actors and to underestimate the influence of the market on their own investment decisions (undervalue of external influences). A company can do everything right on an individual economic level, but fail on the macroeconomic one. The games presented are therefore also suitable for manager training. Students can gain experience in economic interrelationships, which will protect them from wrong decisions in their later 
professional practice.

The results support the Wicksell hypothesis and the above-described findings by Kampmann and Sterman (1996) and Kampmann (1992) and Shachat and Zhang (2012) but contradict the Efficient Market Hypothesis. Further research is important to analyze the collective mistakes of humans as market players. Even if it is difficult to find consistent behavior patterns, in future economic theory will have to rely more on the real behavior of market players than on model-oriented theoretical assumptions.

\section{References}

Conrad, C. A. (2015). Incentives, Risk and Compensation Schemes: Experimental Evidence on the Importance of Risk Adequate Compensation. Applied Economics and Finance, 2(2), 50-55. https://doi.org/10.11114/aef.v2i4.1053

Conrad, C. A. (2019). The effects on investment behavior of zero interest rate policy, evidence from a roulette experiment. Applied Economics and Finance, 6(4), 18-27. https://doi.org/10.11114/aef.v6i4.4272

Conrad, C. A. (2020). Political Economy. Wiesbaden: Springer-Gabler. https://doi.org/10.1007/978-3-658-30884-1

Conrad, C. A. (2021). The Effects of Money Supply and Interest Rates on Stock Prices, Evidence from Two Behavioral Experiments. Applied Economics and Finance, 8(2), 33-41. https://doi.org/10.11114/aef.v8i2.5173

Ezekiel, M. (1938). The Cobweb Theorem. The Quarterly Journal of Economics, 52(2), 255-280. https://doi.org/10.2307/1881734

Fama E. (1970). Efficient capital markets: a review of theory and empirical work. Journal of Finance, 25(2), 383-417. https://doi.org/10.2307/2325486

Glöser-Chowhound, S., Hartwig, J., Wheat, I. D., \& Faulstich M. (2017). The cobweb theorem and delays in adjusting supply in metals' markets, System Dynamics Review 32(4), 279-308. https://doi.org/10.1002/sdr.1565

Grosskettler, H. (1989). Johan Gustav Knut Wicksell. In J. Starbatty (Ed). Klassiker des ökonomischen Denkens II (pp. 191- 210). Munich: Beck.

Humphreys D. (2012). Mining investment trends and implications for minerals availability. Polinares Working Paper, 15 , Brussels.

Kampmann C. E. (1992). Feedback complexity and market adjustment: an experimental approach. PhD thesis, MIT Sloan School of Management, Cambridge, MA.

Kampmann, C., \& Stermann, J. D. (1996). Feedback complexity, bounded rationality, and market dynamics. Mimeo. Retrieved from http://web.mit.edu/jsterman/www/SDG/feed.pdf

Leontief W. (1966). Essays in Economics. Theories and theorizing. London: Oxford University Press.

Menkhoff, L., \& Röckemann, C. (1994). Noise Trading auf Aktienmärkten. Zeitschrift für Betriebswirtschaftslehre, 64(3), 277-295.

Morishima M. (1996). Dynamic Economic Theory. Cambridge, UK: Cambridge University Press. https://doi.org/10.1017/CBO9780511628474

Popper, K. (1958). The Logic of Scientific Discovery. New York: Harper Torchbooks.

Shachat, J., \& Zhang, Z. (2012). The Hayek hypothesis and long run competitive equilibrium: an experimental investigation. Xiamen University Discussion Paper, 21 June 2012. https://doi.org/10.2139/ssrn.2089077

Shleifer, A. (2000). Inefficient markets, an introduction to behavioral finance. Oxford: Oxford University Press. https://doi.org/10.1093/0198292279.001.0001

Simon, H. A. (1959). Theories of Decision-Making in Economics and Behavioral Science. The American Economics Review, 49(3).

Sloan, A., \& Stern, R. L. (1988). How Vo=VgN(d1) - E/ert N(d2) led to black Monday. Forbes, 25(1), 55-59.

Thaler, R. (1989). The psychology of choice and the assumptions of economics. In A. E. Roth (Ed.), Laboratory experimentation in economics. Six points of view (pp. 99-130). New York: Cambridge University Press. https://doi.org/10.1017/CBO9780511528316.004

Waugh F. V. (1964). Cobweb models. American Journal of Agricultural Economics, 46, 732-750. https://doi.org/10.2307/1236509

Wicksell, K. (1922). Vorlesungen über Nationalökonomie auf Grundlage des Marginalprinzipes: Bd. 2. Geld und Kredit. 1969 Aalen: Scienta (first published Stockholm 1906).

Wicksell, K. (1968). Geldzins und Güterpreise. Eine Studie über den Tauschwert des Geldes bestimmenden Ursachen. 
Aalen: Scienta (first published Jena 1898).

Zame W. (2008). General equilibrium (new developments). In Durlauf, S. N. \& Blume L. E. (Eds), The New Palgrave Dictionary of Economics (2nd ed.). London: Palgrave Macmillan. https://doi.org/10.1057/978-1-349-95121-5_2354-1

\section{Copyrights}

Copyright for this article is retained by the author(s), with first publication rights granted to the journal.

This is an open-access article distributed under the terms and conditions of the Creative Commons Attribution license which permits unrestricted use, distribution, and reproduction in any medium, provided the original work is properly cited. 